\title{
The Determinants of FDI in OIC Countries
}

\author{
Sulaiman Sajilan ${ }^{1}$, Muhammad Umar Islam² ${ }^{2}$ Mohsin Ali $^{3} \&$ Urooj Anwar ${ }^{4}$ \\ ${ }^{1}$ Universiti Kuala Lumpur Business School, Malaysia \\ ${ }^{2}$ School of Accounting and Finance, Asia Pacific University of Technology and Innovation, Kuala Lumpur, \\ Malaysia \\ ${ }^{3}$ Taylor's Business School, Taylor's University, Subang Jaya, Malaysia \\ ${ }^{4}$ Independent Researcher, Kuala Lumpur, Malaysia \\ Correspondence: Urooj Anwar, Independent Researcher, Kuala Lumpur, Malaysia.
}

Received: April 30, 2019

doi:10.5430/ijfr.v10n5p466
Accepted: May 30, 2019

Online Published: June 11, 2019

URL: https://doi.org/10.5430/ijfr.v10n5p466

\begin{abstract}
Foreign Direct investment (FDI) is considered to be an important source of capital especially in developing countries. FDI supplements local savings and brings a series of benefits in host countries. This research has focused OIC on countries since these countries are still far behind in attracting FDI compared to other developing countries. OIC member countries inhibit diversity in their resources from resource rich to resource poor countries. They lack behind the developed world in terms of economic development pertaining to weak economies. Since for these types of countries FDI can prove to be a vital source of capital, it becomes important to study the factors that affect it. This study exactly does the same by incorporating a series of determinants (inflation, size of the economy, trade openness, infrastructure, and institutional quality) to assess the impact they have in attracting FDI. We have used data for 42 countries spanning over 1996-2013. The choice of data selection has been dictated by data availability. For estimation we have used panel fixed effects and random effects estimators. Our results indicate that size of economy, infrastructure and trade openness are positively and significantly related in attracting FDI in those countries. Institutions on the other hand are negatively related. The effects of inflation are somewhat mixed according to our estimation and not robust. The implications of our findings are that policy makers should expend efforts in making more trade oriented policies, improve infrastructure and increase the size of economy.
\end{abstract}

Keywords: foreign direct investment, OIC, institutional quality, panel data

JEL: F21, E22, C22

\section{Introduction}

Knowledge of the factors that influence foreign direct investment (FDI) (Note 1) has attracted the attention of economists and policy makers for the last few decades. This is especially true for developing countries since one of the remarkable features of globalization is the flow of FDI in these countries which is considered to be an important source of development finance. It contributes to productivity gains by providing new investment, better technology, management expertise and export markets. FDI in contrast to portfolio or other investments is more stable, longer term and less volatile (Shahrin \& Abdul, 2008). It is considered to be an engine of competition, innovation, know-how and managerial skills, thus it improves the productivity and performance of local firms in host economies (Bengoa and Sanchez-Robles, 2003; Toros, 2018). By bridging the gap between domestic savings and investment and bringing the latest technology and management know-how from developed countries, FDI can play important role in achieving economic growth in developing countries (Khondoker, 2007). Organization of Islamic countries (OIC) is a large international organization which includes 57 member Islamic countries that belong to several sub regional groupings. The members include oil rich countries, newly industrialized nations, service based economies and least developing countries. Some OIC countries are resource rich and others are resource poor (Note 2). The overall progress dilemma facing the majority of OIC members has been a subject of serious concern. Many domestically and regionally grown factors combine to make it difficult for these countries to achieve sustained development. It is widely accepted now that financing choices like FDI could serve as one of the factors to bring these countries out of the vicious circle of underdevelopment. Also it should help these countries to overcome the problems of scarcity of capital that impede the productive use of other factors of production that are in abundance in 
these countries (Majeed \& Ahmad). Over the last three decades, foreign capital sources including FDI have played a vital role and accounting for a significant share of the total investment in many developing countries including OIC members. As both the advanced and developing countries have shown rising interest in attracting FDI, the competition for FDI inflows has intensified (Bissoon, 2011; Nurulhuda, Hasan \& Mohd 2018). The amount of FDI inflows might differ across countries since some countries are more suited to attract FDI than others (Baklouti \& Boujelbene, 2014; Tyagi \& Siddiqui 2017). Indeed, for a variety of reasons related to economic structures and policy issues, developing countries in general, and the least-developed ones in particular, are still less equipped than their developed counterparts to take advantage of the potential of liberalization and globalization to stimulate their economic growth and development. FDI flows have been significantly rising worldwide since early 1990s. World total FDI flows have increased by almost 7 times from $\$ 207.5$ billion in 1990 to $\$ 1400.5$ billion in 2000 . They reached the peak in 2007 with $\$ 1975.5$ before affecting by the global financial crisis, which led to a contraction in FDI flows worldwide, to reach $\$ 1309$ billion in 2010. Yet, with a $16.5 \%$ increase, FDI flows worldwide amounted to $\$ 1524.4$ billion in 2011. It is also worth mentioning that, over the last three decades, the share of the developing countries in world FDI flows was increasing steadily from $16.8 \%$ in 1990 to $51 \%$ in 2011 (Note 3). In contrast, the share of the developed countries was decreasing steadily from $83.2 \%$ to $49 \%$ during the same period. However, as for the OIC member countries, though they constitute a substantial part of the developing countries, FDI flows into the group were generally unsatisfactory. The total FDI flows to all OIC member countries increased from only $\$ 6.8$ billion in 1990 to $\$ 12$ billion in 2000, and reached their peak of $\$ 145.8$ billion in 2007 before decreasing to $\$ 134$ billion in 2011 (Figure 1). During the period since 1990, the 10.3\% maximum share of OIC member countries in total worldwide FDI flows has been recorded in 2010 and decreased to $8.8 \%$ in 2011. It is also observed that FDI flows into OIC member countries are still concentrated in a few of them. For example, in 2011, only five countries (Indonesia, Saudi Arabia, Turkey, Kazakhstan, and Malaysia) accounted for 52\% of the total FDI flows to all OIC countries. And, together with Nigeria, UAE, Iran, Lebanon and Turkmenistan, these 10 countries accounted for $71 \%$ of total FDI flows to all OIC countries (Figure 2) (Note 2).

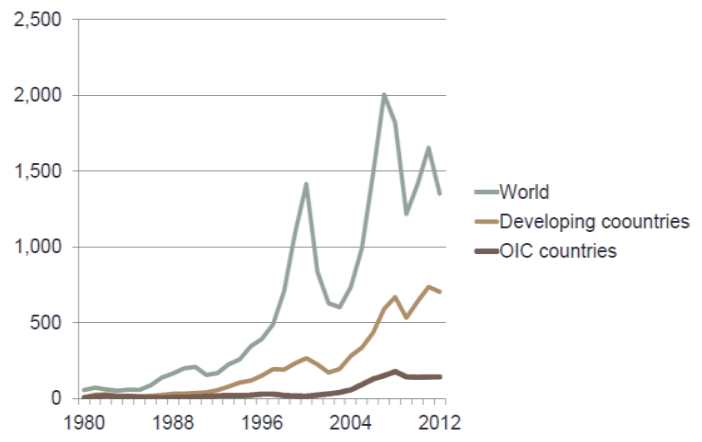

Figure 1. UNCTAD Data: FDI Inflows billion of dollars

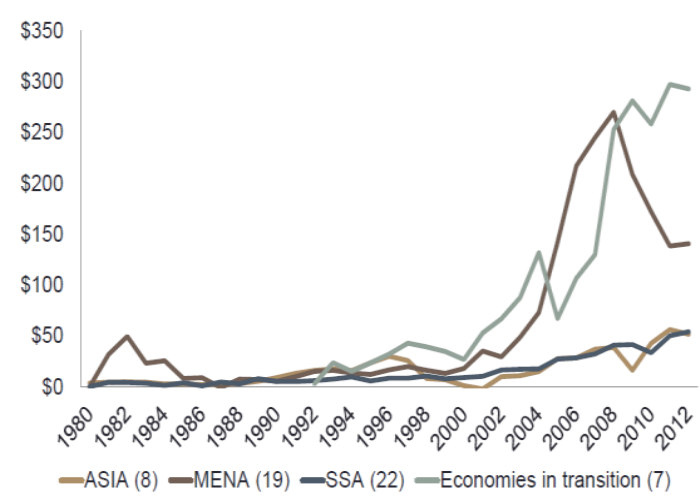

Figure 2. FDI Inflows by Region: billion of dollars 
Given this state of affairs, it seems that most of the OIC countries are still not able to create a favorable economic environment and to provide the required conditions to attract more FDI flows. To achieve this goal, reforms are needed to improve the business climate and to introduce investment incentives for foreign investors. This requires, among others, building adequate infrastructure and investment in modern technologies to enhance their productive capacities, which is still more of a challenge in the majority of them.

By keeping in mind the importance of FDI for growth especially in capital deficit countries like majority of OIC members, it becomes important to analyze the factors that attract it. There have been numerous country wide and regional studies in developed and emerging markets to study the relationship between the FDI and its determinants. These studies have produced mixed results over time and in different cross-sectional settings. The focus of this paper is to analyze the factors that possibly affect FDI in OIC countries for a period of 1996-2013. It attempts to explore the co-integrating relationship between the macroeconomic variables and FDI since there is dearth of literature in this area for OIC countries. This study will fill the gap in this area by providing more recent evidence.

\section{Literature Review}

Economic theory postulates that inflation, market size, trade openness, infrastructure and institutions are important variables in developing an understanding of the behavior of FDI. Past Studies show mixed results since determinants of FDI might be different in countries depending upon their unique characteristics. Also the same determinants might affect FDI differently in different countries. Foreign investors look for certain important factors that range from economic, legal, institutional, political etc. when embarking on investment in a certain country.

\subsection{Inflation}

The steady increase of price level leads to the decrease in the value of domestic assets, increase in risk and this phenomenon is also reflected in the exchange rate. Inflation thus is expected to have a negative relationship with FDI inflows. Asiedu (2002) examined the determinants of FDI in Africa and concluded that low inflation rate promotes FDI. The benefit of investing would fall in the event of rising inflation rate as it erodes purchasing power of consumers in the host country. Most empirical studies have found that inflation rate has negative influence on FDI inflows. It implies that the role of macroeconomic stabilizing policies is crucial in order to attract and stimulate FDI inflows. Despite most of the studies finding significance for inflation, Kolstad \& Villanger, (2008) concluded that inflation has no significant association with FDI especially towards the services industry. Another study by Azam \& Lukman, (2010) found inflation rate to be an insignificant determinant of FDI inflows in Pakistan and Indonesia but significant in India. The relationship between Inflation and FDI is hypothesized to be negative in the case of OIC (Ali \& Haseeb, 2019; Toros, 2018).

\subsection{Market Size}

Market size hypothesis suggests that FDI is a positive function of the market size of the host country. In a way market size reflects the total demand of local consumers in a country where foreign firms are looking for investment. Market size is usually measured by the GDP of the host country. Most empirical studies support the market size hypothesis e.g. (Shamsuddin, 1994; Ahmad \& Ahmed, 2014; Khan and Nawaz, 2010; Sahoo et. al., 2014; Taruvinga, et.al 2017). The growth theory reveals that economies with a larger market size are expected to grow faster because of the benefits of the scale of economies. Therefore, it is supposed that inward FDI will tend to flow in countries that have larger market size. Hence we expect a positive relationship by market size and FDI in OIC countries.

\subsection{International Trade (Trade Openness)}

Higher degree of openness causes higher inflow of foreign capital. The key hypothesis from various theories is that gains from FDI are far higher in the export promotion regime than the import promotion regime. Open to the global market through international trade can also provide scale economies similar to the countries with large domestic market to the foreign investors. Trade openness generally positively influences the export-oriented FDI inflow into an economy (UNCTAD 2009). Investors generally want bigger markets and like to invest in countries that have regional trade integration and also in countries where there are greater investment provisions in their trade agreements. Buthe \& Milner (2008) examined how trade agreements like GATT, WTO and PTAs can be useful to attract FDI into developing countries. Developing countries that belong to the WTO and participate in more PTAs experience greater FDI inflows, controlling for many factors including domestic policy preferences and taking into account possible endogeneity. Joining international trade agreements allows developing countries to attract more FDI and thus increase economic growth. Nourbakhshian et al., (2012); Nkiru, Sidi \& Abomeh (2018), showed in their study that international trade has positive impact on FDI, considered to the MNCs searching for a better business environment, competitive price labor skills, and sharper global competition to lead the MNCs in finding a lower 
production cost country (Jermsittiparsert, 2016). Hence we expect the trade openness-FDI relationship to be positive.

\subsection{Infrastructure}

An improvement in infrastructure is expected to increase FDI in host countries. Good infrastructure increases the productivity of investments and therefore stimulates FDI inflows. Ahmad \& Ahmed (2014) argue that inclination of foreign investors always remains towards those countries which facilitate them in terms of both infrastructure and favorable policies for investments. There are numerous other studies (Tayebiniya \& Khorasgani 2018;Azam \& Lukman, 2010; Asiedu, 2002, Ioannatos, 2003 etc.) that confirm the positive impact of infrastructure on FDI. Since OIC countries has been experiencing a moderate improvement in its technological and communications based infrastructure we carry on with the theoretical foundation of a positive relationship between infrastructure and FDI

\subsection{Institutional Quality}

Considering the importance of macroeconomic factors in attracting FDI inflows, recent studies have highlighted the essential role played by institutional factors in creating a more attractive investment climate (Nasir and Hassan, 2011; Teba, 2017). The importance of linkage between institutional quality and economic performance has been well documented and debated in literature. It's been a known fact now that intuitional quality moderates most economic relationships e.g. finance-growth nexus, FDI-growth nexus etc. Douglas North (1990) was among the first to emphasize the placement of institutional capital, besides physical or intellectual capital in economic equations for assessing macroeconomic performance. Institutional factors are characterized by property rights protection, rule of law, the effective use of resources, and the absence of violence, barriers and restrictive policies etc. These factors are important and have been taken into consideration in most investment decisions and for this reason many developing countries have focused on promoting their institutional quality in order to benefit from FDI's advantages (Chaib \& Siham, 2014; Teh,et.al 2018).

\section{Data and Methodology}

The data for the research is spread over yearly observations from 1996-2013, for total of 17 years. The inclusion of time and countries (42 OIC member countries out of 57) is dictated by data availability. Data on macroeconomic variables has been collected from World Development Indicators while for institutional quality has been fetched from PRS's ICRG database. Institutional quality variables include government stability, corruption, democratic accountability and bureaucratic quality. These institutional quality variables have been rescaled and averaged to get a single indicator of institutional quality for every country.

The specific equation of interest that is expected to tie the variables together is

$$
\mathrm{FDI}_{\mathrm{it}}=\beta_{0}+\beta_{1} \mathrm{LCPI}_{\mathrm{it}}+\beta_{2} \mathrm{LGDPPC}_{\mathrm{it}}+\beta_{3} \mathrm{LTRADE}_{\mathrm{it}}+\beta_{4} \mathrm{LINF}_{\mathrm{it}}+\beta_{5} \mathrm{LINS}_{\mathrm{it}}+\epsilon_{\mathrm{it}}
$$

Where:

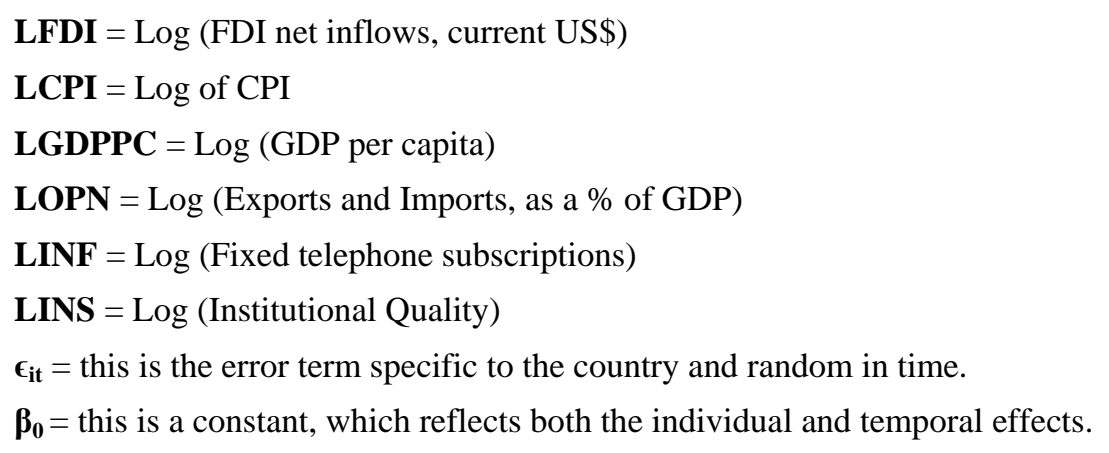

The expected signs are: $\beta_{1}>0$, that is, Institutional quality has positive impact on FDI; $\beta_{2}>0$, that is, inflation has a negative effect on FDI inflows; $\beta_{3}>0$, that is, GDP per capita affects FDI positively; $\beta_{4}>0$ Trade openness affects FDI positively and finally, $\beta_{5}>0$ i.e., the effect of infrastructure is expected to be positive on FDI.

We now discuss estimation procedure for our model. The use of pooled time-series and cross section data provides large sample that is expected to yield efficient parameter estimates. Since economic, political, infrastructural and institutional characteristics vary from country to country, imposing a single relationship to all units is likely to suppress information. In order to overcome this problem, we will use the approach of uniform shifts. The econometric literature suggests two approaches for uniform shifts (Green, 1993; Gujarati, 2004; Nxumalo \& Naidoo 2018), the fixed effects and the random effects estimator. In this study we will primarily use fixed effect while random effects results will used as a robustness check. The fixed effects approach assumes that the shifts are 
deterministic. Here the intercept term is allowed to vary while random variations are assumed to be independent across the cross sections. The term "fixed effects" is due to the fact that, although the intercept may differ across individuals (here the 42 OIC countries), each individual's intercept does not vary over time; that is, it is time invariant. The reformulation of equation 1 employing fixed effects estimator is as follows.

$$
\mathrm{FDI}_{\mathrm{it}}=\beta_{0 \mathrm{i}}+\beta_{1} \text { LCPI }_{\mathrm{it}}+\beta_{2} \text { LGDPPC }_{\mathrm{it}}+\beta_{3} \mathrm{LTRADE}_{\mathrm{it}}+\beta_{4} \mathrm{LINF}_{\mathrm{it}}+\beta_{5} \mathrm{LINS}_{\mathrm{it}}+\epsilon_{\mathrm{it}}
$$

Where $\beta_{\mathrm{i}}$ is country specific fixed effects since by applying OLS with dummies is the fixed effects model. Summary statistics of the data are presented in Table 1.

Table 1. Descriptive statistics

\begin{tabular}{cccccc}
\hline Variable & Obs. & Mean & Std Dev. & Min & Max \\
\hline FDI & 684 & $1,800,000,000$ & $4,070,000,000$ & $(4,550,000,000)$ & $39,500,000,000$ \\
CPI & 664 & 76 & 25 & 2 & 168 \\
GDPPC & 689 & 6,214 & 11,595 & 196 & 60,290 \\
TRADE & 639 & 75 & 38 & 18 & 220 \\
INF & 697 & $2,266,581$ & $5,137,345$ & - & $40,900,000$ \\
\hline INS & 697 & 5 & 1 & - & 7 \\
\hline
\end{tabular}

Table 1 presents the descriptive statistics for the variables under study. From the table it's very obvious that OIC countries are very much different from each other on the basis of concerned measures. This is in line with their economic realities since these economies range from oil rich countries, agriculture based economies, industrialized nations and service based economies.

For instance the average FDI inflows are $\$ 1.8$ billion while the maximum value is 39.5 billion. There is a great deal of diversity in inflation as measured by CPI while the mean value is 76 with an average dispersion of 25 . GDP per capita, Trade as a percentage of GDP and infrastructure also shows significant differences. These major differences are due to large variations in the economic fundamentals of OIC countries. OIC include member countries with very different economic structure and fundamentals.

Table 2. The determininants of FDI using fixed and random effects estimator

\begin{tabular}{lcccc}
\hline \multirow{2}{*}{$\begin{array}{l}\text { Dependent } \\
\text { Variable }\end{array}$} & Fixed Effects Estimator & & \multicolumn{2}{c}{ Random Effects Estimator } \\
& FDI Inflows & & FDI Inflows & \\
\hline LCPI & Coefficient & Probability & Coefficient & Probability \\
LGDPPC & 0.004601 & 0.978 & 1.04469 & 0.000 \\
LTRADE & 0.24527 & 0.000 & 0.310191 & 0.000 \\
LINF & 0.654192 & 0.000 & 0.698944 & 0.000 \\
LINS & 0.717225 & 0.000 & 0.864859 & 0.000 \\
D-Asia & -1.01598 & 0.004 & -1.41714 & 0.000 \\
D-MENA & -0.30909 & 0.155 & -0.63158 & 0.007 \\
Constant & -0.7573 & 0.000 & -1.20065 & 0.000 \\
R-Squared (within) & 7.911749 & 0.000 & 1.751635 & 0.099 \\
No. of Observations & & 0.5381 & & 0.507 \\
\hline
\end{tabular}


From the table equation 1 can be written as

$$
\mathrm{FDI}_{\mathrm{it}}=7.911-1.0159 \mathrm{LINS}_{\mathrm{it}}+0.004 \mathrm{LCPI}_{\mathrm{it}}+0.24527 \mathrm{LGDPPC}_{\mathrm{it}}+0.654192 \mathrm{LTRADE}_{\mathrm{it}}+.717225 \mathrm{LTL}_{\mathrm{it}}+\epsilon_{\mathrm{it}}
$$

Our results are mostly in line with the previously established theory. For instance GDP per capita is positively and significantly related in attracting FDI confirming the market size hypothesis. A $1 \%$ change in GDP per capita is expected to bring marginal FDI of $.24 \%$. Trade Openness is also positively related to FDI confirming that countries which have more relaxed policies related to their imports and exports attract more FDI. A $1 \%$ increase in export and import as a percentage of GDP is expected to bring an FDI of .65\%. Infrastructure is also positive and significant in both the models confirming the established theory that countries who invest to improve their infrastructure attract more FDI. A $1 \%$ increase in infrastructure is expected to increase FDI by $.71 \%$. Inflation according to our fixed effects estimator is insignificant though positive determinant according to fixed effects estimator. On the contrary the random effects estimator shows inflation to be positively and significantly related to FDI. This might be because a certain level of inflation is important for rate of return generation. Unfortunately the inflation results are not robust. Lastly the findings on institutions are somewhat counter intuitive since a vast majority of literature highlights the significant role of institutions for attracting FDI. This might be because of the vast diversity between OIC countries in terms of their institutional quality and Foreign direct investment levels(Nejad, Agha \& Zadeh 2017).

\section{Conclusion}

This paper has investigated the links between FDI and it various determinants in a panel of 42 OIC countries. The study is important in the sense that most of OIC countries are capital deficit and weak in institutions and infrastructure. For these countries FDI can be a very important source of foreign capital to supplement domestic savings and consequently lead to economic growth. For that matter we took data from 42 OIC member countries. The choice of time series and cross sections was dictated by the data availability. We relied on Panel techniques of Fixed and Random effects to establish the relationship between variables of interest. The main findings can be summarized as follows. We found that size of the economy, trade openness and infrastructure of a country to be positively and significantly related to attract FDI. On the other hand we found institutional quality to be negatively related to FDI inflows. The results on inflation as given by both models were not robust as fixed effects model says its insignificant while random effect displays it to be significantly and negatively related to FDI inflows.

The implications of our findings are that policy makers should expend efforts in devising policies that promote international trade, build infrastructure and increase the size of GDP to attract FDI. As FDI have effects on long-term economic performance, providing a conducive environment for it would ensure long-term economic growth and development in OIC countries.

\section{References}

Ahmad, M. H., \& Ahmed, Q. M. (2014). Does the institutional quality matter to attract the and growth: new evidence from Latin America. European Journal of Political Economy, 19(3), 529-545.

Ali, A., \& Haseeb, M. (2019). Radio frequency identification (RFID) technology as a strategic tool towards higher performance of supply chain operations in textile and apparel industry of Malaysia. Uncertain Supply Chain Management, 7(2), 215-226. https://doi.org/10.5267/j.uscm.2018.10.004

Asiedu, E. (2002). On the Determinants of Foreign Direct Investment to Developing Countries: Is Africa Different?. World Development, 30(1), 107-119. https://doi.org/10.1016/S0305-750X(01)00100-0

Azam, M., \& Lukman, L. (2010).Determinants of foreign direct investment in India, Indonesia and Pakistan: A Quantitative Approach. Journal of Management Sciences.

Baklouti, N., \& Boujelbene, Y. (2014). Impact of Institutional Quality on the Attractiveness of Foreign Direct Investment. Journal of Behavioural Economics, Finance, Entrepreneurship, Accounting and Transport, 2(4), 89-93.

Bengoa, M., \& Sanchez-Robles, B. (2003). Foreign direct investment, economic freedom and growth: new evidence from Latin America. European Journal of Political Economy, 19(3), 529-545. https://doi.org/10.1016/S0176-2680(03)00011-9

Bissoon, O. (2011). Can better institutions attract more foreign direct investment; evidence from developing countries. International Research Journal of Finance and Economics, 82, 142-158.

Buthe, T., \& Milner, H. V. (2008). The politics of foreign direct investment into developing Countries: Increasing FDI through International Trade Agreements?. American Journal of Political Science, 52(4), 741-762. 
https://doi.org/10.1111/j.1540-5907.2008.00340.x

Chaib, P. B., \& Siham, M. (2014). The Impact of Institutional Quality in Attracting Foreign Direct Investment in Algeria. Topics in Middle Eastern and African Economies, 16(2), 142-163.

Green, W. H. (1993). Econometric Analysis (2nd ed.). New York, MacMillan.

Gujarati, D. (2004). Basic Econometrics. McGraw Hill.

Jermsittiparsert, K. (2016). Culture of 'Elephant front legs-hind legs': A debate on the actuality of sexual politics in Thai society. The Social Sciences, 11(1), 20-28.

Khan, R., \& Nawaz, M. (2010). Economic determinants of foreign direct investment in Pakistan. J Economics, 1(2), 99-104. https://doi.org/10.1080/09765239.2010.11884929

Khondoker A, M. (2007). Determinants of foreign direct investment and its impact on economic growth in developing countries. MPRA paper 9457.

Kolstad, I., \& Villanger, E. (2008). Determinants of foreign direct investment in services. European Journal of Political Economy, 24(2), 518-533. https://doi.org/10.1016/j.ejpoleco.2007.09.001

Majeed. M. T., \& Ahmad, E. (2010). Host country charateristics and FDI: Are OIC countries different. Journal of Economic Cooperation and Development, 31(4), 1-28.

Nasir, Z. M., \& Hassan, A. (2011). Economic Freedom, exchange rates stability and FDI in South Asia. The Pakistan Development Review, 50(4). https://doi.org/10.30541/v50i4IIpp.423-433

Nejad, M. A. R. S., Agha, F. N. J., \& Zadeh, Y. F. (2017). QSPM Usage in SWOT Analysis as a Tool for Strategic Management of Caspian Sea Coasts (Case Study: Tourism Development in Caspian Eastern Coast at Gilan Province). Journal of Tourism Management Research, 4(1), 1-11. https://doi.org/10.18488/journal.31.2017.41.1.11

Nkiru, N., Sidi, C. P., \& Abomeh, S. (2018). Impact of Information and Communication Technology on the Performance of Deposit Money Banks in Nigeria. International Journal of Management, 7(4), 225-239. https://doi.org/10.18488/journal.11.2018.74.225.239

Nourbakhshian, M.R., Hosseini, S., Aghapour, A. H., \& Reza, G. (2012). The contribution Of foreign direct investment into home country's development. Journal of Business and Social Science, 3(2), 275-287.

Nurulhuda, S., Hasan, R., \& Mohd, A. (2018). Does Gold Price Lead or Lags Islamic Stock Market and Strategy Commodity Price? A Study from Malaysia. International Journal of Business, 5(6), 146-163. https://doi.org/10.18488/journal.62.2018.56.146.163

Nxumalo, N. L., \& Naidoo, L. D. (2018). A Case Study of Local Government Implementation of the Ward Based Local Economic Development (LED) Program. International Journal of Public Policy and Administration Research, 5(1), 1-23. https://doi.org/10.18488/journal.74.2018.51.1.23

Sahoo, P., Nataraj, G., \& Dash, R. K. (2014). Foreign direct investment in South Asia. New Delhi: Springer India. https://doi.org/10.1007/978-81-322-1536-3

Shahrin, A., \& Abdul, B. (2008). The changing role of FDI in the Malaysian economy: an assessment.

Shamsuddin, A. F. M. (1994). Economic determinant of foreign direct investment in less developing countries. The Pakistan Development Review, 33(1), 41-51. https://doi.org/10.30541/v33i1pp.41-51

Taruvinga, R., Gachira, W., Chiwanza, W., \& Nkomo, D. J. (2017). Comparison of the Lee-Carter and Arch in Modelling and Forecasting Mortality in Zimbabwe. Asian Journal of Economic Modelling, 5(1), 11-22. https://doi.org/10.18488/journal.8/2017.5.1/8.1.11.22

Tayebiniya, N. K., \& Khorasgani, N. S. (2018). The Relationship Between Workplace Spirituality and Job Performance Among Staff of Azad Islamic University, Iran. Humanities \& Social Sciences Reviews, 6(1), 14-18. https://doi.org/10.18510/hssr.2018.613

Teba, S. C. (2017). Using Effective Strategies for Errors Correction in EFL Classes: a Case Study of Secondary Public Schools in Benin. Journal of Education and e-Learning Research, 4(2), 63-71. https://doi.org/10.20448/journal.509.2017.42.63.71

Teh, K. L., Wahab, S. B. A., Osman, S. I. W., Latiff, A. S. A., Zawawi, N. F. M., \& Fazal, S. A. (2018). Factors of Sustainable Firm Performance and the Mediating Role of Strategic Opportunity Recognition: A Conceptual Study. 


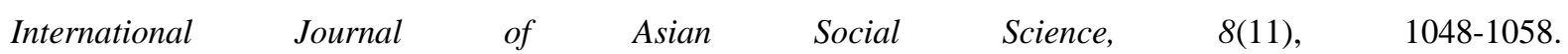
https://doi.org/10.18488/journal.1.2018.811.1048.1058

Toros, T. (2018). Burnout Levels of Handball Players with Respect to Age, Gender and Experience. Asian Journal of Education and Training, 4(1), 29-34. https://doi.org/10.20448/journal.522.2018.41.29.34

Toros, T. (2018). Effect of Verbal Feedback in Twelve Weeks Handball Training on Self-Efficacy and Life Satisfaction. Asian Journal of Education and Training, 4(1), 13-17. https://doi.org/10.20448/journal.522.2018.41.13.17

Tyagi, S., \& Siddiqui, S. (2017). Yield Curve and Momentum Effects in Monthly US Equity Returns: Some Nonparametric Evidence. Asian Journal of Economics and Empirical Research, 4(2), 61-67. https://doi.org/10.20448/journal.501.2017.42.61.67

\section{Notes}

Note 1. According to the definition by World Bank "Foreign direct investment are the net inflows of investment to acquire a lasting management interest" (10 percent or more of voting stock) in an enterprise operating in an economy other than that of the investor. Moreover, it is the sum of equity capital, reinvestment of earnings, other long-term capital, and short-term capital and is shown in the balance of payments.

Note 2. Presentation on FDI trends in OIC countries in the seminar on "Investment policies toward sustainable development and inclusive growth" organized by UNCTAD, IDB and ITAP, 10-13 December 2013, Morocco.

Note 3. SESRIC Workshop on Increasing FDI flows to OIC member countries, 24-25 September, Ankara, Turkey 